\title{
Correction: Alpha-enolase as a potential cancer prognostic marker promotes cell growth, migration, and invasion in glioma
}

Ye Song ${ }^{1,2+}$, Qisheng Luo ${ }^{1,3+}$, Hao Long ${ }^{1 \dagger}$, Zheng Hu${ }^{1}$, Tianshi Que ${ }^{1}, X^{\prime}$ an Zhang ${ }^{1}$, Zhiyong Li ${ }^{1}$, Gang Wang ${ }^{1}$, Liu Yi ${ }^{1}$, Zhen Liu ${ }^{2,4^{*}}$, WeiYi Fang ${ }^{2^{*}}$ and Songtao Qi ${ }^{1^{*}}$

\section{Correction}

After the publication of this work [1] it was brought to the authors' attention that the U251-pLVTHM panel in Figure fiveB and the U251 negative control (NC) panel in Figure fiveD contained a duplication in error. The correct version of Figure five (Figure 1 here) is given below.

The authors regret any inconvenience that this inaccuracy may have caused.

\begin{abstract}
Author details
'Department of Neurosurgery, Nanfang Hospital, Southern Medical University, Guangzhou, Guangdong, PR China. ${ }^{2}$ Cancer Research Institute of Southern Medical University, Guangzhou, Guangdong, PR China.

${ }^{3}$ Department of Neurosurgery, Affiliated Hospital, Youjiang Medical College for Nationalities, Baise, Guangxi, PR China. ${ }^{4}$ Department of Pathology, Basic School of Guangzhou Medical College, Guangzhou, Guangdong, PR China.
\end{abstract}

Received: 16 October 2014 Accepted: 16 October 2014

Published: 20 January 2015

\section{Reference}

1. Song Y, Luo Q, Long H, Hu Z, Que T, Zhang X, et al. Alpha-enolase as a potential cancer prognostic marker promotes cell growth, migration, and invasion in glioma. Mol Cancer 2014, 13:65.

\footnotetext{
* Correspondence: narcissus_jane@163.com; fangweiyi1975@163.com; gisongtaosjwk@163.com

${ }^{\dagger}$ Equal contributors

${ }^{4}$ Department of Pathology, Basic School of Guangzhou Medical College, Guangzhou, Guangdong, PR China

${ }^{2}$ Cancer Research Institute of Southern Medical University, Guangzhou, Guangdong, PR China

'Department of Neurosurgery, Nanfang Hospital, Southern Medical University, Guangzhou, Guangdong, PR China
}

\section{Submit your next manuscript to BioMed Central and take full advantage of: \\ - Convenient online submission \\ - Thorough peer review \\ - No space constraints or color figure charges \\ - Immediate publication on acceptance \\ - Inclusion in PubMed, CAS, Scopus and Google Scholar \\ - Research which is freely available for redistribution




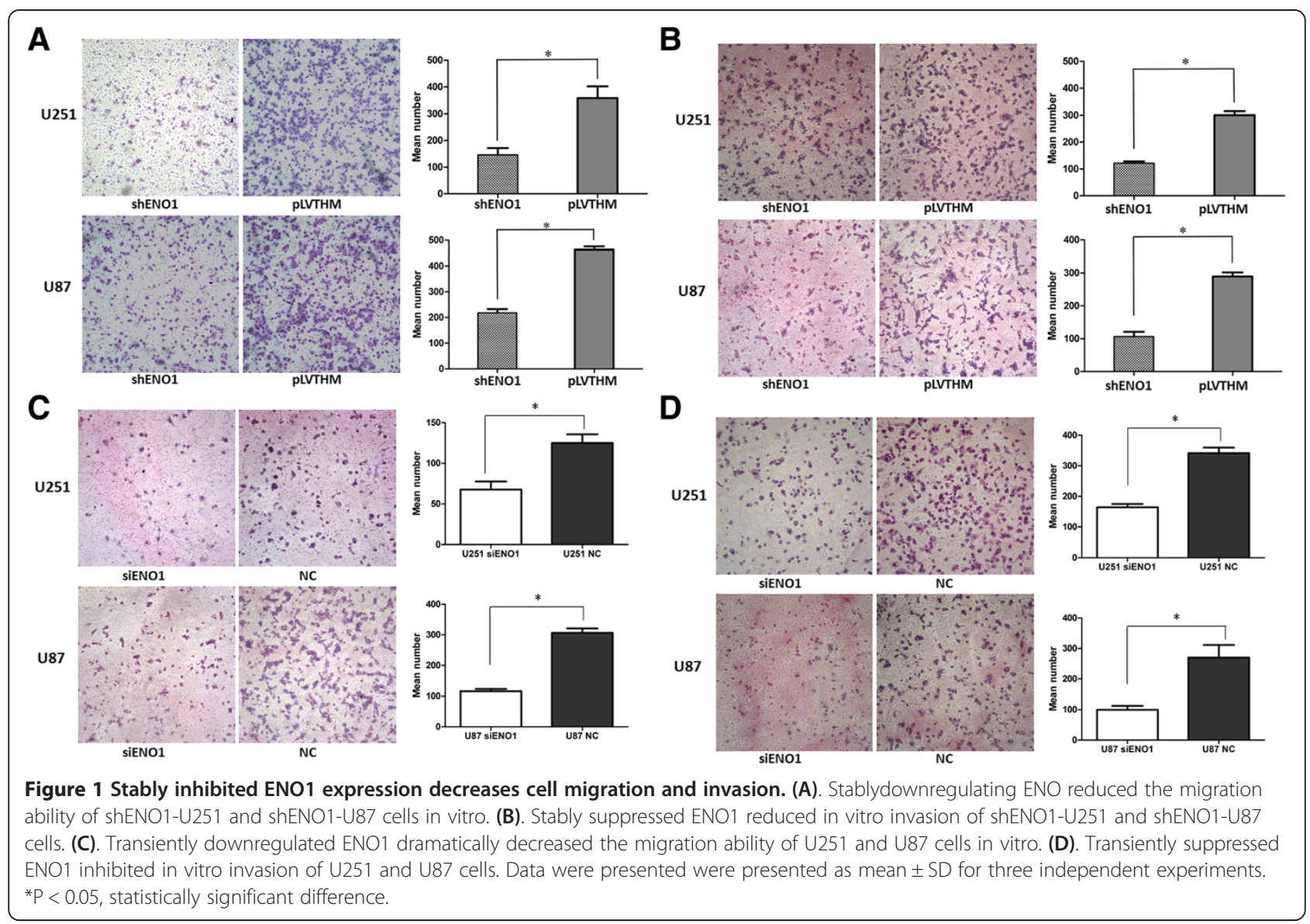

